\section{Abrasive Grit Application in Organic Red Pepper: An Opportunity for Integrating Nitrogen and Weed Management}

\author{
Emily E. Braun, Sarah Taylor Lovell, and Mohammad Babadoost \\ Department of Crop Sciences, University of Illinois, Urbana, IL 61801
}

Frank Forcella

North Central Soil Conservation Research Laboratory, United States Department of Agriculture Agricultural Research Service, 803 Iowa Avenue, Morris, MN 56267

\author{
Sharon Clay \\ Department of Agronomy, Horticulture \& Plant Science, South Dakota State \\ University, Box 2140C, University Station, Brookings, SD 57007
}

\section{Daniel Humburg}

Department of Agricultural Machinery Engineering, South Dakota State University, Brookings, SD 57007

\section{Sam E. Wortman ${ }^{1}$ \\ Department of Agronomy and Horticulture, University of Nebraska-Lincoln, 279 Plant Sciences Hall, Lincoln, NE 68583}

Additional index words. integrated crop management, organic weed management, plasticulture

\begin{abstract}
Weeds are a top management concern among organic vegetable growers. Abrasive weeding is a nonchemical tactic using air-propelled abrasive grit to destroy weed seedlings within crop rows. Many grit types are effective, but if organic fertilizers are used, this could integrate weed and nutrient management in a single field pass. Our objective was to quantify the effects of abrasive grit and mulch type on weed suppression, disease severity, soil nitrogen availability, and yield of pepper (Capsicum annuum $\mathrm{L}$. 'Carmen'). A 2-year experiment was conducted in organic red sweet pepper at Urbana, IL, with four replicates of five abrasive grit treatments (walnut shell grits, soybean meal fertilizer, composted turkey litter fertilizer, a weedy control, and a weed-free control) and four mulch treatments (straw mulch, bioplastic film, polyethylene plastic film, and a bare soil control). Abrasive weeding, regardless of grit type, paired with bioplastic or polyethylene plastic mulch reduced in-row weed density (67 and $87 \%$, respectively) and biomass (81 and 84\%); however there was no significant benefit when paired with straw mulch or bare ground. Despite the addition of 6 to $34 \mathrm{~kg} \mathrm{~N} / \mathrm{ha} / \mathrm{yr}$ through the application of soybean meal and composted turkey litter grits, simulated plant $\mathbf{N}$ uptake was most influenced by mulch composition (e.g., plastic vs. straw) and weed abundance. Nitrogen immobilization in straw mulch plots reduced leaf greenness, plant height, and yield. Bacterial spot (Xanthomonas campestris pv. Vesicatoria) was confirmed on peppers in both years, but abrasive weeding did not increase severity of the disease. Pepper yield was always greatest in the weed-free control and lowest in straw mulch and bare soil, but the combination of abrasive weeding (regardless of grit type) and bioplastic or polyethylene plastic mulch increased marketable yield by $47 \%$ and $21 \%$, respectively, compared with the weedy control. Overall, results demonstrate that when abrasive weeding is paired with bioplastic or polyethylene mulch, growers can concurrently suppress weeds and increase crop $\mathbf{N}$ uptake for greater yields.
\end{abstract}

\footnotetext{
Received for publication 22 Apr. 2019. Accepted for publication 5 June 2019 .

This research was funded in part by the U.S. Department of Agriculture, National Institute of Food and Agriculture (USDA NIFA), Organic Agriculture Research and Extension Initiative (OREI), award 2014-51300-22233, and the Nebraska Agricultural Experiment Station with funding from the Hatch Act (accession 1014303) through the USDA NIFA. We thank Michael Douglass for his excellent field technical support.

${ }^{1}$ Corresponding author. E-mail: swortman@unl.edu.
}

2012). Because tillage disturbs the soil surface, there is a potential for soil degradation including the loss of soil aggregate structure and organic matter, and increased erosion (Munkholm et al., 2013). Tillage can also increase weed seedbank density by distributing and burying newly shed weed seeds; similarly, soil disturbance can bring buried weed seeds near the surface to facilitate germination (Bond and Grundy, 2001; Melander and Rasmussen, 2000).

Current alternatives to tillage for weed management in organic systems include mulching with plastic films, straw, or cover crops and organic herbicides, mowing, flame weeding, laser treatment (Mathiassen et al., 2006), hot oil microdosing (Zhang et al., 2012), and steam and hot water (Kristoffersen et al., 2008). Mulching can provide seasonlong weed control along with improved crop performance through increases in available water and enhanced efficiency of irrigation systems (Sarkar et al., 2007; Sarkar and Singh, 2007). Mulching with straw or cover crop residues increases soil moisture and reduces weed growth, but it is usually less effective than black plastic mulch film for weed management (Anzalone et al., 2010). The volume of organic mulch required for effective weed management can be cost-prohibitive and logistically challenging to transport if not produced on or near the farm. Organic mulch residues are biodegradable, but decomposition during the growing season can result in untimely microbial immobilization of essential plant nutrients (Bond and Grundy, 2001). Moreover, straw and hay mulches can carry weed seeds and increase seed bank density (Schonbeck, 1999).

Plastic and biodegradable plastic mulch films are commonly used for weed management in vegetable production, but weeds can emerge through any uncovered space, including crop holes or tears in the plastic (Schonbeck, 1999; Wortman, 2015). Plastic films increase soil temperature (Lamont, 2005) and increase water use efficiency (Moreno and Moreno, 2008), especially when integrated with drip or subsurface drip irrigation (Anzalone et al., 2010). The biggest drawback to plastic mulch film is that it must be removed from the field after harvest, and disposal has economic and environmental consequences (Kasirajan and Ngouajio, 2012; Miles et al., 2012).

Concerns about plastic mulch film disposal have led to the development of biodegradable alternatives. Biodegradable plastic mulch film can degrade into nontoxic compounds, although more stable degradable polymers may remain in the soil as microfragments for extended periods of time (Fontanelli et al., 2013; Kasirajan and Ngouajio, 2012; Miles et al., 2012). Most biodegradable plastic mulches provide similar agronomic services as polyethylene plastic, though polyethylene is more effective for increasing soil temperature (Moreno and Moreno, 2008). The main barrier to on-farm adoption of biodegradable mulch films is the higher cost, which is a result of the higher 
costs of raw materials (Fontanelli et al., 2013). Paper mulch (e.g., WeedGuardPlus; SunShine Paper, Aurora, CO) is the only biodegradable mulch currently allowed as a soil input on U.S. Department of Agriculture (USDA) certified organic farms, but it can be difficult to install, is susceptible to damage from high winds, and often degrades before the end of the growing season, leading to weed establishment (Anderson et al., 1996; Anzalone et al., 2010; Schonbeck, 1999).

Despite recent innovations in nonchemical weed management tactics, flame weeding remains among the most common alternatives to tillage on organic farms (Baker and Mohler, 2015). Flame weeding with propane gas does not disturb the soil, which can help to minimize weed seed germination; however, flaming has been shown to increase germination of some weed species (Ascard, 1995; Bond and Grundy, 2001; Taylor et al., 2012). Flame weeding can be done in wet soils, and application timing is generally more flexible than tillage because it does not require soil disturbance. One drawback of flame weeding is the potential for crop injury and yield loss when applied in the row (Ulloa et al., 2010). However, crops like garlic (Allium sativum) can tolerate up to three flame treatments for in-row weed management without any reduction in productivity (Chehade et al., 2018). Despite its effectiveness in field crops, flame weeding cannot be used to manage in-row weeds (e.g., those in the crop hole) in mulched or plasticulture vegetable production because the mulch or films could catch fire or melt.

Abrasive weeding is a relatively new approach to organic weed management that uses compressed air to propel agricultural grits, including fertilizers, at weed seedlings to physically destroy emerged structures (Forcella, 2009a; Wortman, 2014). A diverse range of materials have demonstrated effectiveness as grits for abrasive weeding, including granulated corn gluten meal, corn cobs, greensand fertilizer, walnut shells, and soybean meal (Wortman, 2014). Abrasive weeding applications may also be used to supplement in-season crop nutrition if organic fertilizers (e.g., soybean meal) are used as the grit source, which could lead to additional gains in crop growth, yield, and profitability of this weed management tactic. Moreover, delaying plant available soil nitrogen early in the growing season could shift the outcome of crop-weed competition in favor of crops and better synchronize nutrient mineralization with peak crop demand (Liebman and Davis, 2000; Wortman et al., 2011).

Abrasive weeding has been studied in corn and soybean (Carlson et al., 2018; Erazo-Barradas et al., 2019), but less research has been conducted in vegetable crops considering interactions with unique cropping system attributes such as mulch films (Wortman, 2014, 2015). Although abrasive weeding has been used successfully to manage weeds in plasticulture tomato and pepper (Wortman, 2015), it is not known if this technology is compatible with other types of agricultural mulch or if it is suitable for use in systems without mulch. There are also questions about the effects of abrasive weeding on crop health. Stem and leaf injury after abrasive weeding in vegetables may increase susceptibility to disease by providing an entry point for pathogens (Wortman, 2014), but that potential risk has not been quantified. Lastly, the opportunity for integrating nitrogen and weed management with abrasive grit applications has been proposed (Forcella et al., 2011), but actual soil nitrogen contributions and potential plant nitrogen uptake from abrasive weeding have not been quantified.

The overall aim of this study was to determine the effectiveness of abrasive weeding in organic sweet red pepper (Capsicum annuum L. 'Carmen') production. Specific objectives were to 1) quantify the effects of different grit types on weed suppression, disease severity, soil nitrogen availability and potential crop uptake, and crop yield and 2) determine the compatibility of abrasive weeding with different types of mulch for nonchemical, in-row weed management.

\section{Materials and Methods}

Experimental design. Field experiments were conducted in 2015 and 2016 at the University of Illinois Sustainable Student Farm in Urbana, IL (40.08N, 88.22W; elevation $221 \mathrm{~m})$. The predominant soil texture is loam ( $31 \%$ sand, $45 \%$ silt, and $24 \%$ clay), and the farm has been managed according to USDA National Organic Program guidelines since its inception in 2009.

This experiment was set up as a factorial with two treatments (grit and mulch type) in a randomized complete block design with four replicates. The five abrasive grit type treatments included soybean meal fertilizer (Phyta-grow Leafy Green Special, 7N-0.4P1.6K; California Organic Fertilizers, Inc., Hanford, CA), composted turkey litter (Suståne, 8N-0.9P-3.3K; Suståne Natural Fertilizer, Inc., Cannon Falls, MN), walnut shell grit (Kramer Industries, Inc., Piscataway, NJ), a nontreated weedy control, and a hand-weeded weed-free control. The four mulch types included polyethylene plastic film, biodegradable plastic film (Bio360, Dubois Agrinovation, Saint-Rémi, Quebec, Canada), straw mulch (Miscanthus spp.), and a bare soil control. This experimental design resulted in 80 experimental units (five grittype treatments $\times 4$ mulch type treatments $\times 4$ replicates). Each experimental unit was $3.25 \mathrm{~m}^{2}$ (4.27 $\mathrm{m}$ long $\times 0.76 \mathrm{~m}$ wide $)$ and included nine pepper plants (Capsicum annuum L. cv. 'Carmen') spaced $0.46 \mathrm{~m}$ apart.

Crop management. In both years, raisedbed tops were $0.76-\mathrm{m}$ wide with $1.06-\mathrm{m}$ alleys (measured from the edge of each bed top). Drip tape irrigation line with $15-\mathrm{cm}$ emitter-spacing was laid down the center of each bed top. Peppers were irrigated regularly to maintain a minimum of $15 \%$ volumetric soil moisture within the top 7-cm of the bed top. Plastic and biodegradable plastic films were laid using a combined bed shaper and mulch layer (RB 448; Nolt's Produce Supplies, Leola, PA). Straw mulch, chopped in 5- to 10-cm segments, was spread by hand on each bed top to achieve uniform coverage to a depth of $\approx 7.5 \mathrm{~cm}$. Weeds in alleys between bed tops and experimental units were managed with mowing and hand weeding.

Pepper plants were transplanted on 22 May 2015 (9 weeks after sowing) and 24 May 2016 (8 weeks after sowing), and then trellised on 2 June 2015 and 16 June 2016 using the basket weave method common in tomatoes (Solanum lycopersicum L.). Plants were fertigated via drip irrigation system immediately after transplanting with fish emulsion (Ferti-lome Fish Emulsion Fertilizer, $5 \mathrm{~N}-0.4 \mathrm{P}-0.8 \mathrm{~K}$ ) and seaweed extract (Ohrstrom's Maxicrop Liquid Seaweed, $0 \mathrm{~N}-0 \mathrm{P}-0.8 \mathrm{~K})$, each at a $1: 100$ dilution ratio. With the exception of abrasive grit applications (experimental treatments), peppers received no additional fertilizer during the experiment.

Following recommendations from previous research (Forcella, 2012; Erazo-Barradas et al., 2019; Wortman, 2015), abrasive grits were applied two times per season and scheduled when weeds were between the cotyledon and two-leaf growth stage. The first grit application in 2015 occurred $14 \mathrm{~d}$ after transplanting (DAT) in bare soil, polyethylene plastic, and biodegradable plastic mulch plots, and 19 DAT in straw mulch plots due to delayed emergence and growth of weed seedlings. The second grit application was made 31 DAT for all treatments. In 2016, abrasive grits were applied for the first time at 10 DAT in bare soil, polyethylene plastic, and biodegradable plastic mulch plots and 15 DAT in straw mulch plots. Second grit applications in 2016 were made 27 DAT in bare soil, polyethylene plastic, and biodegradable plastic mulch plots and 37 DAT in straw mulch plots. Ambient weed communities were dominated by annual broadleaf $(68 \%-80 \%)$ and grass $(20 \%-32 \%)$ species, including Amaranthus spp., Chenopodium album L., and Setaria viridis (L.) P. Beauv.

In 2015, abrasive grits (between 0.42 and $0.84 \mathrm{~mm}$ diameter) were applied using handheld, gravity-fed sand-blasting guns (Speed Blaster; Zendex Tool Corporation, Danbury, CT). Compressed air was fed through the gun at $\approx 689 \mathrm{kPa}$ using an air compressor (BelAire Compressors; Rock Hill, SC; Model $3 \mathrm{G} 3 \mathrm{HH}$ ) mounted on a tool bar and hauled by a small tractor (Kubota; Grapevine, Texas; BX1870-1). Abrasive grits were applied in a continuous strip $(20-\mathrm{cm}$ band) within the crop row for bare soil and straw mulch plots, but only within individual planting holes for polyethylene plastic and biodegradable plastic mulch plots. In 2016, abrasive grits were applied using a prototype abrasive grit applicator, similar to that used by Erazo-Barradas et al. (2019). Compressed air $(\approx 931 \mathrm{kPa})$ propelled grits from the prototype nozzles in this applicator, but unlike the sand-blasting 
Table 1. Average application rates for one field pass of each grit type, application method (spot spray in the crop hole vs. continuous spray in the entire crop row), and year (gravity-fed sand-blasting applicator guns used in 2015 vs. prototype nozzle and grit-metering system in 2016). Linear and area estimates assume an average tractor speed of $1.6 \mathrm{~km} \cdot \mathrm{h}^{-1}$ and crop row spacing of $1.83 \mathrm{~m}$. Two applications were made in each year.

\begin{tabular}{|c|c|c|c|c|c|c|c|c|c|}
\hline \multirow[b]{3}{*}{ Grit type } & \multicolumn{6}{|c|}{2015} & \multirow{2}{*}{\multicolumn{3}{|c|}{$\begin{array}{c}2016 \\
\text { Continuous spray }\end{array}$}} \\
\hline & \multicolumn{3}{|c|}{ Spot spray } & \multicolumn{3}{|c|}{ Continuous spray } & & & \\
\hline & $\overline{\mathrm{g} / \mathrm{m} \text { row }}$ & $\mathrm{kg} \cdot \mathrm{ha}^{-1}$ & $\overline{\mathrm{kg} \mathrm{N} / \mathrm{ha}}$ & $\overline{\mathrm{g} / \mathrm{m} \text { row }}$ & $\mathrm{kg} \cdot \mathrm{ha}^{-1}$ & $\overline{\mathrm{kg} \mathrm{N} / \mathrm{ha}}$ & $\mathrm{g} / \mathrm{m}$ row & $\mathrm{kg} \cdot \mathrm{ha}^{-1}$ & $\overline{\mathrm{kg} \mathrm{N} / \mathrm{ha}}$ \\
\hline Soybean meal & 6.7 & 37 & 3 & 20.4 & 111 & 8 & 39.4 & 215 & 17 \\
\hline Composted turkey litter & 6.3 & 34 & 3 & 15.0 & 82 & 7 & 34.6 & 189 & 15 \\
\hline Walnut shell & 4.9 & 27 & 0 & 11.8 & 64 & 0 & 35.7 & 195 & 0 \\
\hline
\end{tabular}

Table 2. Effects of mulch and abrasive grit type on in-row weed density (plants $/ \mathrm{m}^{2}$ ) sampled $\approx 1$ month (early season) or $\approx 2$ months (late season) after transplanting peppers, and aboveground weed biomass $\left(\mathrm{g} \cdot \mathrm{m}^{-2}\right.$ ) sampled 2 months (2016) or 4 months (2015) after transplanting peppers. Data were pooled across 2015 and 2016 for analysis.

\begin{tabular}{|c|c|c|c|}
\hline \multirow[b]{2}{*}{ Treatments } & \multicolumn{2}{|c|}{ Weed density (plants $/ \mathrm{m}^{2}$ ) } & \multirow{2}{*}{$\begin{array}{l}\text { Aboveground } \\
\text { biomass }\left(\mathrm{g} \cdot \mathrm{m}^{-2}\right)\end{array}$} \\
\hline & Early season & Late season & \\
\hline \multicolumn{4}{|l|}{ Bare soil } \\
\hline Weedy control & $357 \mathrm{a}$ & $181 \mathrm{a}$ & $624 \mathrm{c}$ \\
\hline Soybean meal & $223 \mathrm{ab}$ & $115 \mathrm{a}$ & $351 \mathrm{~cd}$ \\
\hline Composted turkey litter & $302 \mathrm{ab}$ & $137 \mathrm{a}$ & $453 \mathrm{~cd}$ \\
\hline Walnut shell & $225 \mathrm{ab}$ & $99 \mathrm{a}$ & $286 \mathrm{~cd}$ \\
\hline \multicolumn{4}{|l|}{ Bioplastic } \\
\hline Weedy control & $55 \mathrm{bc}$ & $27 \mathrm{~b}$ & $1800 \mathrm{a}$ \\
\hline Soybean meal & $25 \mathrm{~cd}$ & $11 \mathrm{bc}$ & $438 \mathrm{~cd}$ \\
\hline Composted turkey litter & $16 \mathrm{cde}$ & $11 \mathrm{bc}$ & $317 \mathrm{~cd}$ \\
\hline Walnut shell & 14 cde & $3 \mathrm{~cd}$ & $263 \mathrm{~cd}$ \\
\hline \multicolumn{4}{|l|}{ Polyethylene } \\
\hline Weedy control & $52 \mathrm{bc}$ & $25 \mathrm{~b}$ & $1220 \mathrm{~b}$ \\
\hline Soybean meal & 11 cde & $3 \mathrm{~cd}$ & $176 \mathrm{~cd}$ \\
\hline Composted turkey litter & 8 cde & $3 \mathrm{~cd}$ & $243 \mathrm{~cd}$ \\
\hline Walnut shell & $5 \mathrm{de}$ & $3 \mathrm{~cd}$ & $168 \mathrm{~cd}$ \\
\hline \multicolumn{4}{|l|}{ Straw mulch } \\
\hline Weedy control & $27 \mathrm{~cd}$ & $33 \mathrm{~b}$ & $320 \mathrm{~cd}$ \\
\hline Soybean meal & $11 \mathrm{cde}$ & $22 \mathrm{~b}$ & $195 \mathrm{~cd}$ \\
\hline Composted turkey litter & $25 \mathrm{~cd}$ & $33 \mathrm{~b}$ & $124 \mathrm{~d}$ \\
\hline Walnut shell & $27 \mathrm{~cd}$ & $30 \mathrm{~b}$ & $87 \mathrm{~d}$ \\
\hline
\end{tabular}

Different letters within columns indicate significant differences among grit type $\times$ mulch treatmen combinations $(P<0.05)$. Data were $\ln (\mathrm{x}+1)$ transformed for analysis, but back-transformed least squares means are presented.

guns, the flow of grits could not be easily turned on and off with a trigger; thus, abrasive grits were applied in a continuous strip within crop rows for all plots (i.e., grits were applied to plastic and biodegradable plastic mulch between plants).

In both years, one person drove the tractor at a constant speed of $1.6 \mathrm{~km} \cdot \mathrm{h}^{-1}$, while a second person walked behind the tractor holding the applicator nozzle to apply grits (the prototype applicator used in 2016 can be operated by one person on a tractor, but a second person was used in this experiment to improve application precision in our small research plots). Applicator tips were held 20 to $30 \mathrm{~cm}$ from the soil surface and aimed at the intersection of pepper stems and the soil surface. Application rates were determined for each grit type and applicator by weighing grit in the hopper before and after application in each plot (Table 1).

Data collection. In-row weed density was measured at 31 DAT in 2015 and 27 DAT in 2016 within two quadrats $(91 \times 20 \mathrm{~cm})$ placed randomly within the crop row (hereafter referred to as early-season sampling interval). Weed density was measured again at 61 DAT (2015) or 59 DAT (2016) within the crop row (hereafter referred to as late-season sampling interval). Aboveground weed biomass was collected from all plots 123 DAT in 2015, and 62 DAT in 2016. Weed biomass samples were collected from each plot within two $91 \times$ $20 \mathrm{~cm}$ quadrats placed within the crop row. Weeds were clipped at the soil surface, dried at $60{ }^{\circ} \mathrm{C}$ to constant mass, and weighed. Weed biomass was collected earlier in 2016 to prevent weed seed rain and seedbank regeneration at the farm. The critical weedfree period for pepper is estimated to include the first half of the growing season (AmadorRamírez, 2002), so the earlier sampling of weed biomass (near the beginning of the second half of the growing season) was not expected to alter yield estimates significantly across years.

Approximately every 2 weeks after transplanting, plant height and leaf greenness were measured from three random plants per plot. Plant height was measured as the height of the plant from the base of the stem to the top of the newest, fully emerged leaf extended vertically. Leaf greenness was measured near the center of the newest fully emerged leaf using a handheld greenness sensor (atLEAF+; FT Green LLC, Wilmington, DE).

Soil samples were collected before planting to determine baseline nitrogen levels and again after first frost in the fall using soil probes fitted with $46-\mathrm{cm}$ dry sampling tubes with 1.9-cm diameter (Model PN001; Clements Associates, Inc., Newton, IA;). Four $20-\mathrm{cm}$ cores were removed from each plot within alternating planting holes and aggregated for nitrate and ammonium analysis via $\mathrm{KCl}$ extraction (Ward Laboratories, Inc. Kearney, NE).

Potentially plant available soil nitrogen after grit applications was measured using ion exchange resin stakes (PRS Probes; Western Ag Innovations, Saskatoon, Saskatchewan, Canada). Pairs of anion and cation resin stakes were buried to a depth of $14 \mathrm{~cm}$ within four alternating planting holes within the soybean meal, composted turkey litter, and weed-free control plots 1 week after the first grit application in both years (eight stakes per plot). Each set of stakes remained in the field for 2 weeks, then replaced by a new set of stakes in the exact same location. Resin stakes were buried for a total of four 2-week intervals, resulting in an 8 -week sampling period ( 1 to 9 weeks after first grit application). Upon field removal, probes were washed with reverse osmosis water and sent to Western $\mathrm{Ag}$ Innovations for analysis of nitrate and ammonium (reported as a relative measure among treatments specific to this experiment; $\mu \mathrm{g} \mathrm{N} / 10 \mathrm{~cm}^{2} / 2$ weeks). Ion exchange resin membranes are an increasingly common tool for continuously monitoring mineral soil nitrogen during the growing season, and the data are often positively correlated with point measurements of soil nitrogen, plant nitrogen uptake, and crop yield (Nyiraneza et al., 2009).

Visual symptoms of plant diseases were scouted weekly and when observed, confirmed via microscopic analysis or laboratory culture. After confirmation of bacterial spots on leaves, plants were treated with copper hydroxide (Champ WG; Nufarm Limited, Alsip, IL) to curtail the spread of the pathogen. During the growing season, disease severity was estimated with visual ratings of percent leaf area affected on three random plants per plot. Severity ratings were recorded in nearest percent estimates and averaged across the whole plot. Ratings from $0 \%$ to $15 \%$ were estimated to the nearest $1 \%$, but ratings greater than $15 \%$ were estimated to the nearest $5 \%$.

Pepper fruit were harvested at maturity throughout the season and sorted by marketable and cull fruit, and counted and weighed. Yield data were pooled across dates for estimates of season-long yield parameters. Cull fruit included those that had visual signs 

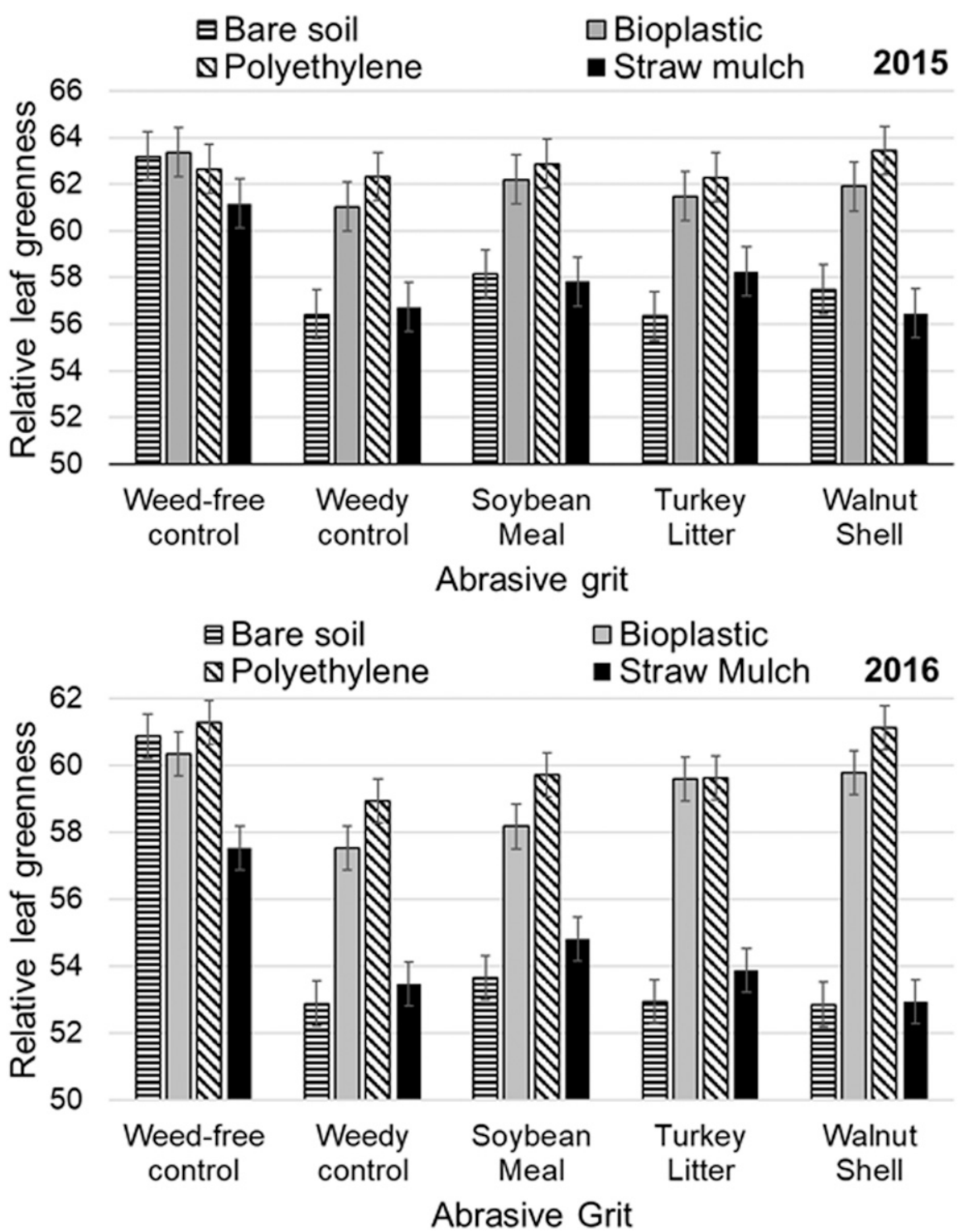

Fig. 1. Effects of grit and mulch type on relative leaf greenness (as measured by atLEAF+) in 2015 (top) and 2016 (bottom). Data are pooled across multiple sampling dates between Julian days 167 and 261. Error bars represent $\pm 1 \mathrm{SE}$.

of bacterial spot, sunscald, decay, or significant damage from insects or frost.

Statistical analysis. Analysis of variance was performed on all data using the 'GLIMMIX' procedure in SAS (v9.4; SAS Institute, Cary, NC) to determine potential differences among experimental treatments. Replicate block was the random effect, while abrasive grit type, mulch type, year, and their two- and three-way interactions were treated as fixed effects. In the absence of treatment by year interactions, the model was simplified by pooling across years for analysis. Repeated measures analysis was used for nitrogen data from PRS Probes, and leaf greenness, plant height, and disease rating data. Data for leaf greenness, plant height, and disease ratings were analyzed by year due to different data collection dates between years. Least square means were calculated and compared among treatments using the Tukey-Kramer multiple comparisons test that abrasive weeding reduced early-season weed density by $67 \%$ and $85 \%$ when paired with bioplastic $(P=0.0005)$ and polyethylene $(P<0.0001)$ mulch, respectively.

Late-season, in-row weed density was again influenced by the interaction of abrasive grit and mulch type $(P<0.0001)$. Weed density was greatest in the bare soil plots, and the weed control efficacy of abrasive grits were insignificant when not paired with a mulch film (Table 2). Straw mulch alone reduced weed density by $82 \%$ compared with the bare soil weedy control, and abrasive weeding did not provide additional weed management benefits in that mulch type. However, abrasive weeding paired with polyethylene plastic and bioplastic mulch film provided additive weed management benefits. For example, polyethylene plastic alone reduced weed density by $86 \%$, and the addition of abrasive weeding reduced weed density by a total of $98 \%$ compared with the bare soil weedy control (regardless of abrasive grit type). Results were similar for bioplastic mulch, but only the walnut shell grits provided a significant reduction in weed density beyond the mulch alone. Although walnut shell grits were slightly more effective than the other grit types tested, orthogonal contrasts suggest that abrasive weeding (regardless of grit type) paired with bioplastic $(P<0.0001)$ and polyethylene plastic $(P<0.0001)$ mulch reduced late-season weed density by $70 \%$ and $88 \%$, respectively, compared with their respective weedy controls.

In laboratory tests to determine the most effective abrasive grit sources, Pérez-Ruiz et al. (2018) found that walnut shell grits outperformed other tested grit sources in the penetration of test papers and in the removal of tested weeds. Similarly, Wortman (2014) found that granulated walnut shell grits were more effective in reducing weed biomass than granulated corn cob grits or a bone meal fertilizer. As suggested by Forcella (2009b), the irregular and rigid angles of the walnut shell grits may aid in cutting and shredding weed seedling tissue.

In-row aboveground weed biomass was driven by the interaction of abrasive grit and mulch type $(P<0.0001)$ and was greatest in weedy control plots of polyethylene and bioplastic mulch films (Table 2). Considering late-season, in-row weed density results, it is clear that individual weeds in the bioplastic and polyethylene mulch plots were much larger than those in the straw mulch or bare soil plots (i.e., more grams per plant). The agronomic services of plastic mulch film that benefit crops, including increased soil temperature and moisture (Lamont, 1993), seem to indiscriminately benefit weeds growing in the crop hole as well. Although weed biomass among abrasive grit types was similar across mulch treatments, orthogonal contrasts suggest abrasive weeding (regardless of grit type) was effective in reducing in-row weed biomass in bioplastic $(P<0.0001)$ and polyethylene $(P<0.0001)$ plastic mulch plots by $81 \%$ and $84 \%$, respectively. 


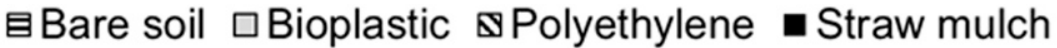

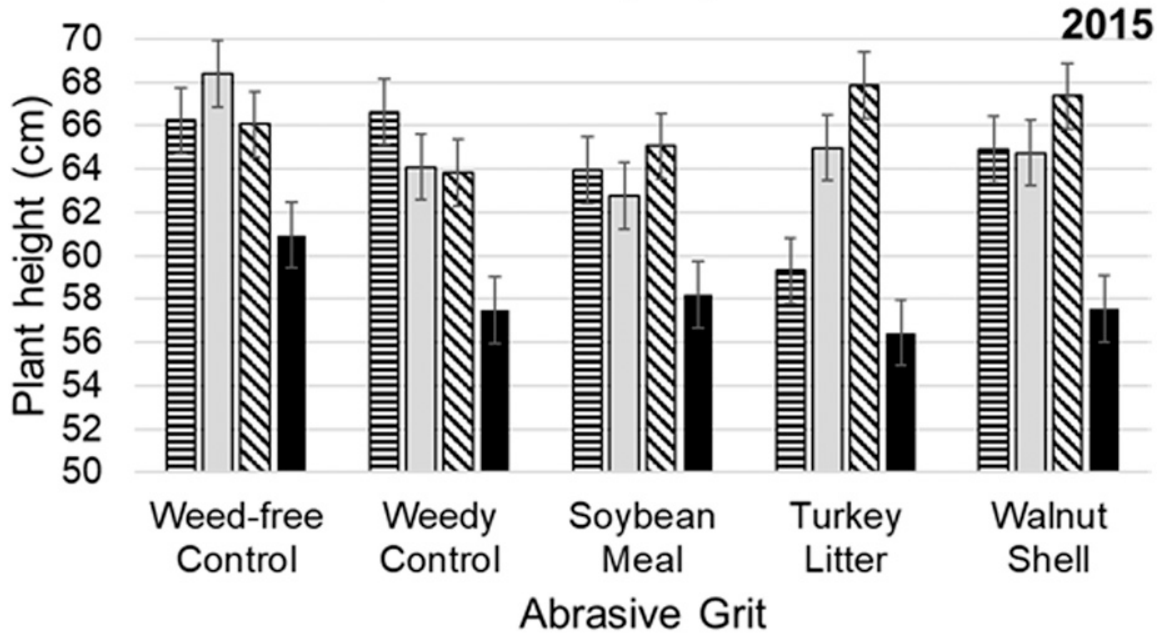

\section{\#Bare soil $\square$ Bioplastic $\$$ Polyethylene $\square$ Straw mulch}

66

2016

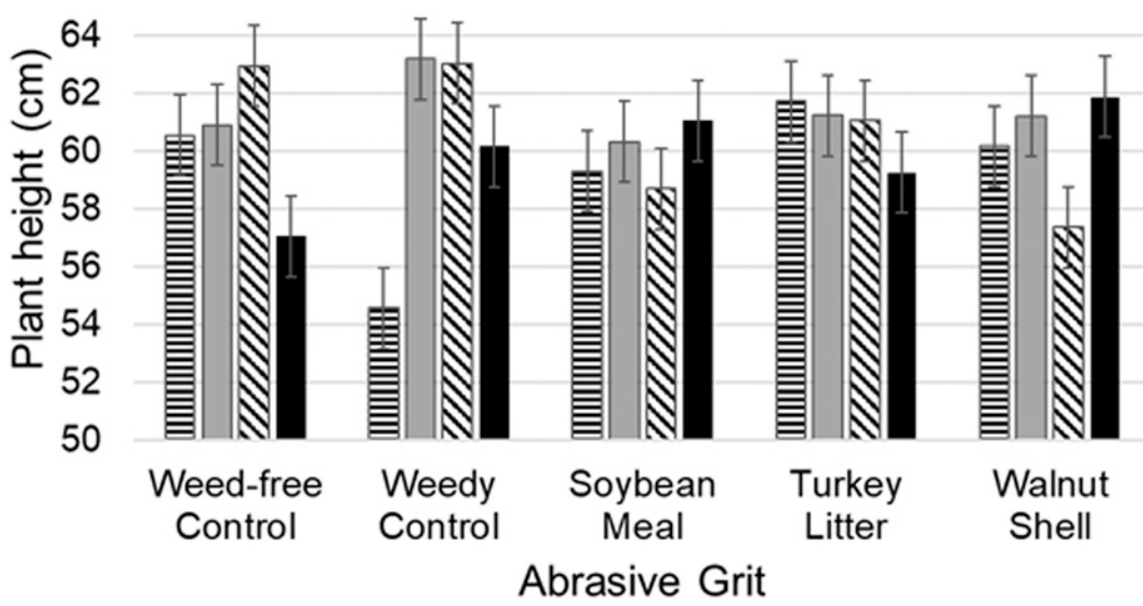

Fig. 2. Effects of grit and mulch type on mean pepper plant height (centimeters) in 2015 (top) and 2016 (bottom). Data are pooled across multiple sampling dates between Julian days 166 and 261. Error bars represent $\pm 1 \mathrm{SE}$.

Table 3. Simulated plant uptake $\left(\mu \mathrm{g} / 10 \mathrm{~cm}^{2} / 2\right.$ weeks of burial) of soil mineral nitrogen $\left(\mathrm{NO}_{3}-\mathrm{N}+\right.$ $\mathrm{NH}_{4}-\mathrm{N}$ ) as influenced by the interaction of selected grit and mulch type treatments. Data are pooled across years (2) and incubation periods (four per year) for analysis.

\begin{tabular}{lc}
\hline Treatments & $\begin{array}{c}\mathrm{NO}_{3}-\mathrm{N}+\mathrm{NH}_{4}-\mathrm{N} \\
\left(\mu \mathrm{g} / 10 \mathrm{~cm}^{2} / 2 \mathrm{wk}\right)\end{array}$ \\
\hline Weed-free control & $176 \mathrm{ab}$ \\
Bare soil & $153 \mathrm{bc}$ \\
Bioplastic & $175 \mathrm{ab}$ \\
Polyethylene & $70 \mathrm{~d}$ \\
Straw mulch & \\
Soybean meal & $98 \mathrm{~cd}$ \\
Bare soil & $200 \mathrm{ab}$ \\
Bioplastic & $215 \mathrm{a}$ \\
Polyethylene & $84 \mathrm{~d}$ \\
Straw mulch & \\
Composted turkey litter & $110 \mathrm{~cd}$ \\
Bare soil & $172 \mathrm{ab}$ \\
Bioplastic & $227 \mathrm{a}$ \\
Polyethylene & $66 \mathrm{~d}$ \\
Straw mulch &
\end{tabular}

Different letters indicate significant difference among treatments $(P<0.05)$.
Reductions in end-of-season weed biomass following abrasive grit applications have not been consistent among cropping systems. Wortman (2015) reported weed biomass reductions in the crop hole of plastic mulch film of up to $69 \%$ in tomato and $97 \%$ in pepper after abrasive grit treatment. It was concluded that reduced efficacy of abrasive weeding in tomato was due to greater weed density and size at the time of grit application. Weed density in the nontreated, weedy control plots of mulched plots in this study ranged from 27 to 55 plants $/ \mathrm{m}^{2}$, which is greater than weed densities observed by Wortman (2015). However, grits were applied at appropriately small growth stages (i.e., earlier than two-leaf stage) in this study, which likely contributed to strong weed biomass suppression despite abundant initial weed density. In-row weed biomass in maize (Zea mays L.) was reduced by $88 \%$ in one season and not different from the weedy control in another season (Erazo-Barradas et al., 2019). Similarly, Carlson et al. (2018) found that grit application in maize and soybean [Glycine $\max (\mathrm{L}$.) Merr.] generally reduced broadleaf weed density but did not affect end-of-season in-row weed biomass. Interrow cultivation and flame weeding were used to manage between-row weeds in both of these previous studies, but the modest and often insignificant weed biomass suppression is congruent with results from this study when abrasive weeding was deployed in the absence of mulch (i.e., no significant reduction of in-row weed biomass). Together, results suggest that abrasive weeding may be most suitable for use in combination with physical barriers of weed suppression and as a targeted weed management tool.

Leaf greenness and crop growth. Relative leaf greenness in 2015 was affected by interactions of abrasive grit and mulch type $(P=0.0081)$, abrasive grit and time $(P=$ $0.0029)$, and mulch type and time $(P<$ 0.0001). Pepper leaf greenness in 2015, averaged across all sampling intervals, was generally greatest in bioplastic and polyethylene plastic mulch plots and lowest in straw mulch and bare soil plots, regardless of abrasive grit type (Fig. 1). Increased competition with weeds (not the mulch itself) appeared to be the largest driver of reductions in leaf greenness because greenness was similar among mulch types in the weed-free control. Leaf greenness is a reliable proxy for leaf chlorophyll content (Zhu et al., 2012), and reduced greenness likely resulted in reduced photosynthesis, crop growth rate, and yield (Wortman, 2015).

Leaf greenness declined more rapidly over time in the weedy-control plots compared with plots treated with abrasive grits and the weed-free control (data not shown). This suggests reduced weed density and biomass in grit-treated plots (Table 2) may have helped to mitigate interspecific resource competition and subsequent plant nutrient deficiencies (Iqbal and Wright, 1997). Leaf greenness also declined over time in the bare soil and straw mulch plots but remained relatively stable in polyethylene and bioplastic plots (data not shown). Leaf greenness was not different among mulch types at $31 \mathrm{~d}$ after transplanting (DAT), but by 96 DAT, leaf greenness was $10 \%$ to $13 \%$ lower in straw mulch and bare soil plots compared with bioplastic and polyethylene mulch plots, respectively.

Leaf greenness in 2016 was similar to 2015 and again influenced by interactions of abrasive grit and mulch type $(P<0.0001)$, abrasive grit and time $(P<0.0001)$, and mulch type and time $(P=0.0004)$. Seasonlong leaf greenness was greatest in the weedfree treatments (excluding straw mulch, which reduced greenness) and the polyethylene and bioplastic mulch plots that received abrasive grit treatment (regardless of grit type; Fig. 1). Leaf greenness was not different among grit treatments and controls at 23 DAT, but at 72 DAT (and thereafter), greenness was greatest in the weed-free control treatment (regardless of mulch type). 

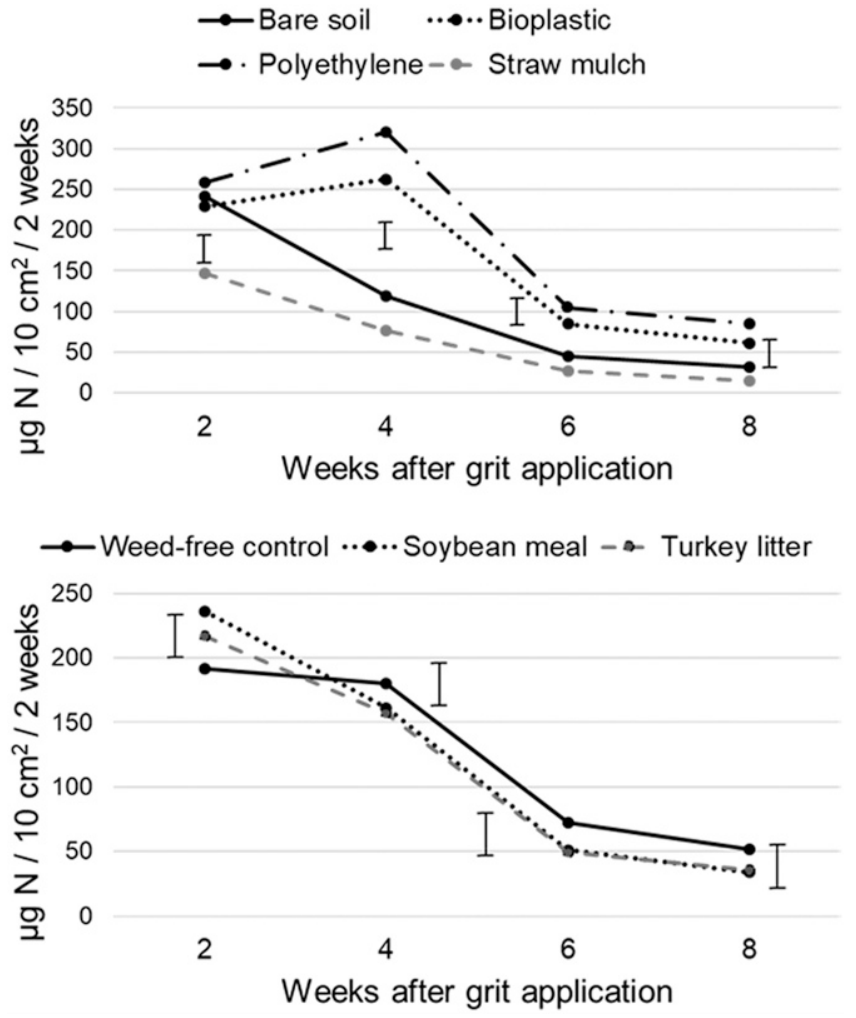

Fig. 3. Effects of mulch (top) and grit type (bottom) on simulated total plant nitrogen $\left(\mathrm{NO}_{3}-\mathrm{N}+\mathrm{NH}_{4}-\mathrm{N}\right)$ uptake ( $\mu \mathrm{g} \mathrm{N} / 10 \mathrm{~cm}^{2} / 2$ weeks) across 2-week incubation periods beginning after the first grit application. Data are pooled across both years of the experiment. Error bars, located adjacent to treatment mean clusters at each time interval, represent $\pm 1 \mathrm{SE}$.

Averaged across grit types, leaf greenness was greatest in polyethylene and bioplastic plots, and that difference became more pronounced as the 2016 season progressed. By 111 DAT, leaf greenness was $9 \%$ and $12 \%$ greater in bioplastic and polyethylene plastic mulch plots compared with bare soil. Plastic mulch films can increase soil temperatures (Lamont, 2005), which can lead to greater net $\mathrm{N}$ mineralization and plant uptake (Liu et al., 2003). This effect, combined with reduced weed competition in and adjacent to the crop row, likely contributed to increased leaf greenness in bioplastic and polyethylene plots by the end of the growing season.

Plant height in 2015 was affected by interactions of abrasive grit and mulch $(P=$ $0.0019)$ and mulch and time $(P=0.0008)$. Plant height was stunted in straw mulch across all grit types and controls (Fig. 2), and the stunting became more pronounced as the season progressed (data not shown). This was likely due to nitrogen immobilization associated with high $\mathrm{C}: \mathrm{N}$ of straw mulch (Döring et al., 2005; Knowles et al., 1993) and is supported by simulated nitrogen uptake data (discussed later). Plant heights in 2016 were again influenced by interactions of abrasive grit and mulch type $(P<0.0001)$ and mulch and time $(P<0.0001)$, but trends were somewhat different. Although straw mulch stunted plant height in the weed-free control, this did not occur in the grit-treated plots. It is possible that intense crop-weed competition for light and increased red:far red light beneath the weed canopy resulted in taller plants due to the expression of shade avoidance (Page et al., 2010). However, this would not explain why plant height was significantly lower in the bare soil weedy control (where we would expect the most intense crop-weed competition for light). Perhaps crop height response to weed competition was quadratic, where height increased with weed density to some upper threshold and then decreased at extremely high weed density levels due to nearly complete light interference and exclusion. Indeed, in-row weed density in 2016 was greatest in the bare soil weedy control ( 329 plants $/ \mathrm{m}^{2}$ ) and much lower in the straw mulch plots (27-53 plants/ $\mathrm{m}^{2}$ ) (data not shown).

Plant available nitrogen. Simulated total plant $\mathrm{N}\left(\mathrm{NO}_{3}-\mathrm{N}+\mathrm{NH}_{4}-\mathrm{N}\right)$ uptake $(\mu \mathrm{g} \mathrm{N} / 10$ $\mathrm{cm}^{2} / 2$ weeks; hereafter abbreviated as " $\mathrm{N}$ uptake") was influenced by interactions of abrasive grit and mulch type $(P<0.0001)$, abrasive grit and time $(P=0.0012)$, and mulch type and time $(P<0.0001)$. Averaged across all incubation periods, $\mathrm{N}$ uptake was greatest in weed-free controls (excluding the straw mulch plots) and in polyethylene and bioplastic mulch, regardless of whether grit was applied (Table 3 ). In contrast, $\mathrm{N}$ uptake was lowest in straw mulch plots (regardless of grit application) and in bare soil plots of soybean meal and composted turkey litter grit treatments; together, results suggest $\mathrm{N}$ uptake was more influenced by mulch composition (e.g., plastic vs. straw) and weed density
(Ponce et al., 1996) than the abrasive grits applied. Indeed, organic mulches can immobilize early-season soil nitrate and reduce vegetable crop yields compared with plastic mulch film (Roe et al., 1994).

Plant $\mathrm{N}$ uptake declined over time across all mulch types but was consistently lowest in straw mulch plots (Fig. 3), presumably due to weed competition and $\mathrm{N}$ immobilization caused by the high $\mathrm{C}: \mathrm{N}$ straw residue (Flavel and Murphy, 2006). Although not a perfect indicator, $\mathrm{C}: \mathrm{N}$ can be used to predict mineralization potential of crop residues and organic soil amendments, and amendments with relatively high $\mathrm{C}: \mathrm{N}$ typically cause short-term immobilization of mineral soil $\mathrm{N}$ after application (Gale et al., 2006). Increased $\mathrm{N}$ uptake in polyethylene and bioplastic plots, especially at 4 weeks after grit application, is consistent with observed increases in leaf greenness and plant height in the same treatments (Figs. 1 and 2). Plant $\mathrm{N}$ uptake and tissue $\mathrm{N}$ are typically correlated with leaf greenness, chlorophyll content, height, and pepper yield (Hartz et al., 1993).

Total plant $\mathrm{N}$ uptake decreased over time for each of the three tested abrasive grits, presumably due to declining soil supply. By 6 and 8 weeks after grit application, uptake was greater in the weed-free control than in the soybean meal or composted turkey litter treatments (Fig. 3). Despite the addition of 6 to $34 \mathrm{~kg}$ organic N/ha/yr with soybean meal and composted turkey litter grits (Table 1), in-row weed competition for soil nitrogen (as a result of incomplete weed control; Table 2) likely limited potential $\mathrm{N}$ uptake in these treatments. Braun (2017) found that a minimum of $36 \mathrm{~kg}$ organic N/ha from abrasive grits was needed to increase kale (Brassica oleracea) yield significantly in a greenhouse study; thus, actual field application rates may have been too low to realize $\mathrm{N}$ uptake benefits (especially when residual weeds were included in the system). Moreover, an unknown but significant portion of the applied grit bounced off of soil and mulch surfaces and into the between-row area where crop $\mathrm{N}$ uptake is less likely.

Disease severity. In 2015, severity of bacterial spot on leaves was affected by interactions of abrasive grit and mulch $(P=$ $0.036)$ and mulch and time $(P<0.0001)$. Severity of the disease was typically lower in grit-treated bare soil plots $(5 \%$ to $7 \%$ diseased tissue) than in the nontreated weed-free plots ( $9 \%$ to $16 \%$ diseased tissue) and grittreated mulched plots $(8 \%$ to $16 \%$ diseased tissue). Most importantly, there was no significant difference in bacterial spot severity between nontreated weed-free plots and grittreated plots (regardless of mulch type; data not shown).

In 2016, severity of bacterial spot was affected by the interaction of mulch and time $(P=0.0005)$. Diseased tissue was lowest in bare soil plots $(6 \%)$ compared with mulched plots $(15 \%$ to $23 \%)$ early in the season, but disease severity was similar among treatments later in the season when disease presence was lower (data not shown). As in 
Table 4. Effects of mulch type and abrasive weeding (pooled across grit types) on marketable and total yield (kilogram/meter row) relative to the weed-free and weedy control plots across both years.

\begin{tabular}{lcc}
\hline Treatments & Marketable yield $(\mathrm{kg} / \mathrm{m}$ row $)$ & Total yield $(\mathrm{kg} / \mathrm{m}$ row $)$ \\
\hline Polyethylene & $3.6( \pm 0.3) \mathrm{a}$ & \\
Weed-free & $2.9( \pm 0.2) \mathrm{b}$ & $5.2( \pm 0.2) \mathrm{a}$ \\
Grit-treated & $2.4( \pm 0.3) \mathrm{c}$ & $4.2( \pm 0.1) \mathrm{b}$ \\
Weedy & & $3.4( \pm 0.2) \mathrm{c}$ \\
Bioplastic & $3.5( \pm 0.3) \mathrm{a}$ & \\
Weed-free & $2.5( \pm 0.2) \mathrm{b}$ & $4.7( \pm 0.2) \mathrm{a}$ \\
Grit-treated & $1.7( \pm 0.3) \mathrm{c}$ & $3.6( \pm 0.1) \mathrm{b}$ \\
Weedy & & $2.6( \pm 0.2) \mathrm{c}$ \\
Straw & $2.5( \pm 0.3) \mathrm{a}$ & \\
Weed-free & $0.7( \pm 0.2) \mathrm{b}$ & $3.7( \pm 0.2) \mathrm{a}$ \\
Grit-treated & $0.5( \pm 0.3) \mathrm{b}$ & $1.2( \pm 0.1) \mathrm{b}$ \\
Weedy & & $0.9( \pm 0.2) \mathrm{b}$ \\
Bare soil & $3.5( \pm 0.3) \mathrm{a}$ & \\
Weed-free & $0.5( \pm 0.2) \mathrm{b}$ & $4.8( \pm 0.2) \mathrm{a}$ \\
Grit-treated & $0.3( \pm 0.3) \mathrm{b}$ & $0.7( \pm 0.1) \mathrm{b}$ \\
Weedy & & $0.6( \pm 0.2) \mathrm{b}$ \\
\hline
\end{tabular}

Yields were compared using orthogonal contrasts of least squares means and different letters within columns for each mulch treatment indicate significant differences $(P<0.05)$.

2015 , there was no difference in severity of bacterial spot on leaves between peppers in nontreated control plots and those that were subjected to mild abrasion from soybean meal, composted turkey litter, or walnut shell grits (data not shown).

Although mulch films can reduce disease incidence and severity by minimizing exposure to soilborne pathogens spread via water splash during intense rainfall events (Granke et al., 2012), bacterial spot has limited survivability in soil. Instead, it is typically spread from plant to plant through water and aerosols, and the high density of weeds growing adjacent to and above the crop canopy in bare soil plots (Table 2) may have physically sheltered plants from this spread (Duczek et al., 1996; Krupinsky et al., 2002). Moreover, the pathogen can be spread among plants in plasticulture when rainwater carries the pathogen across the impermeable mulch surface and into neighboring crop holes (Granke et al., 2012). Intense crop-weed competition may also contribute to increased crop disease due to reduced air movement and increased humidity in the canopy; however, that was not observed in our studies for the severity of bacterial spot in pepper.

Crop yield and quality. Total $(P<0.0001)$ and marketable yield $(P<0.0001)$ were both influenced by the interaction of abrasive grit and mulch type. Yield was always greatest in weed-free plots followed by grit-treated plots (Table 4). Orthogonal contrasts suggest the combination of abrasive weeding (regardless of grit type $)$ and bioplastic $(P=0.0006)$ or polyethylene plastic $(P=0.0426)$ mulch increased marketable yield by $47 \%$ and $21 \%$ compared with their respective weedy controls. Yield gains relative to the weedy control are similar to previous reports of $\approx 44 \%$ in tomato, $30 \%$ in pepper, and $26 \%$ in maize (Forcella, 2012; Wortman, 2015). However, similar to Carlson et al. (2018), the combination of abrasive weeding for in-row weed management and supplemental tactics (e.g., mulches, tillage, or flame weeding) for between-row management still had crop yields less than the weed-free control. Yield loss in weedy compared with weed-free controls ranged from $90 \%$ in bare soil to $45 \%$ in bioplastic to $33 \%$ in polyethylene plastic, which highlights the need for supplemental in-row weed management tactics (e.g., abrasive weeding), even in plasticulture vegetable systems.

We had expected that yields (across grit types) would be greater in bioplastic and plastic mulch film plots relative to bare soil and straw mulch. Several previous studies have demonstrated that plastic mulch film increases crop yields relative to bare, nonmulched soils (Lamont, 1993). Zhang et al. (2019) demonstrated that crop yield in bioplastic film is often similar to that in polyethylene plastic film. Straw mulch did not increase yield relative to bare soil in this study, which was likely due to the combination of insufficient weed management (Table 2) and soil nitrogen immobilization (Table 3; Fig. 1) from the high $\mathrm{C}: \mathrm{N}$ residue. With the exception of the weed-free plots, bioplastic and polyethylene plastic increased yields over bare soil plots across all grit types; the lack of yield benefit in the absence of weeds suggests that the primary benefit of the mulches in this study was weed suppression (not soil moisture conservation or increased soil warming as documented in other studies, e.g., Wortman et al., 2015).

In summary, weed suppression and increased potential for crop $\mathrm{N}$ uptake achieved by combining abrasive weeding with polyethylene or bioplastic mulch films resulted in increased sweet red pepper yield. A partial budget analysis of this system in Wortman et al. (2018) suggests that this yield increase represents a mean net income gain of $\$ 33,265 /$ ha relative to the weedy control in plastic mulch. However, the analysis also indicated that organic farmers could increase net income by an additional $\$ 38,458 /$ ha if all weeds were removed from the crop row by hand weeding (i.e., the weed free control). Although the additional income is desirable, it is not always realistic for organic farmers to achieve weed-free conditions, in part due to the increasingly difficult task of hiring and retaining farm workers in the United States. Although not as effective or profitable as hand weeding, abrasive weeding is mechanized and requires $83 \%$ less labor. Combined with its dual functionality in applying fertilizer, abrasive weeding may be most useful for organic farmers seeking reduced-labor management solutions.

\section{Literature Cited}

Anderson, D.F., M.-A. Garisto, J.-C. Bourrut, M.W. Schonbeck, R. Jaye, A. Wurzberger, and R. DeGregorio. 1996. Evaluation of a paper mulch made from recycled materials as an alternative to plastic film mulch for vegetables. J. Sustain. Agr. 7(1):39-61.

Amador-Ramírez, M.D. 2002. Critical period of weed control in transplanted chilli pepper. Weed Res. 42(3):203-209.

Anzalone, A., A. Cirujeda, J. Aibar, G. Pardo, and C. Zaragoza. 2010. Effect of biodegradable mulch materials on weed control in processing tomatoes. Weed Technol. 24(3):369-377.

Ascard, J. 1995. Effects of flame weeding on weed species at different developmental stages. Weed Res. 35(5):397-411.

Baker, B.P. and C.L. Mohler. 2015. Weed management by upstate New York organic farmers: Strategies, techniques and research priorities. Renew. Agr. Food Syst. 30(5):418-427.

Bond, W. and A.C. Grundy. 2001. Non-chemical weed management in organic farming systems. Weed Res. 41(5):383-405.

Braun, E.E. 2017. Abrasive grit application for integrated weed and nitrogen management in organic vegetable cropping systems. University of Illinois at Urbana-Champaign, Urbana, MS Thesis.

Carlson, M., F. Forcella, S.E. Wortman, and S.A. Clay. 2018. Using abrasive grit for weed management in field crops. In: M.A. El-Ewawi (ed.) Physical properties and physical methods for stimulation of plant and mushroom development. InTech Open, Rijeka, Croatia. 8 July 2019. <https://www.intechopen.com/books/ physical-methods-for-stimulation-of-plant-andmushroom-development/using-abrasive-grit-forweed-management-in-field-crops $>$.

Chehade, L.A., M. Fontanelli, L. Martelloni, C. Frasconi, M. Raffaelli, and A. Peruzzi. 2018. Effects of flame weeding on organic garlic production. HortTechnology 28:502-508.

Döring, T.F., M. Brandt, J. Heß, M.R. Finckh, and H. Saucke. 2005. Effects of straw mulch on soil nitrate dynamics, weeds, yield and soil erosion in organically grown potatoes. Field Crops Res. 94(2):238-249.

Duczek, L.J., L.L. Jones-Flory, S.L. Reed, K.L. Bailey, and G.P. Lafond. 1996. Sporulation of Bipolaris sorokiniana on the crowns of crop plants grown in Saskatchewan. Can. J. Plant Sci. 76(4):861-867.

Erazo-Barradas, M., C.N. Friedrichsen, F. Forcella, D. Humburg, and S.A. Clay. 2019. Propelled abrasive grit applications for weed management in transitional corn grain production. Renew. Agr. Food Syst. 34(1):33-40.

Flavel, T.C. and D.V. Murphy. 2006. Carbon and nitrogen mineralization rates after application of organic amendments to soil. J. Environ. Qual. 35(1):183-193.

Fontanelli, M., M. Raffaelli, L. Martelloni, C. Frasconi, M. Ginanni, and A. Peruzzi. 2013. The influence of non-living mulch, mechanical and thermal treatments on weed population and yield of rainfed fresh-market tomato (Solanum lycopersicum L.). Span. J. Agr. Res. 11(3):593602. 
Forcella, F. 2009a. Potential of air-propelled abrasives for selective weed control. Weed Technol. 23(2):317-320.

Forcella, F. 2009b. Potential use of abrasive airpropelled agricultural residues for weed control. Weed Res. 49(4):341-345.

Forcella, F. 2012. Air-propelled abrasive grit for postemergence in-row weed control in field corn. Weed Technol. 26(1):161-164.

Forcella, F., T. James, and A. Rahman. 2011. Postemergence weed control through abrasion with an approved organic fertilizer. Renew. Agr. Food Syst. 26(1):31-37.

Gale, E.S., D.M. Sullivan, C.G. Cogger, A.I. Bary, D.D. Hemphill, and E.A. Myhre. 2006. Estimating plant-available nitrogen release from manures, composts, and specialty products. J. Environ. Qual. 35(6):2321-2332.

Granke, L.L., L. Quesada-Ocampo, K. Lamour, and M.K. Hausbeck. 2012. Advances in research on Phytophthora capsici on vegetable crops in the United States. Plant Dis. 96(11): $1588-1600$.

Hartz, T.K., M. LeStrange, and D.M. May. 1993. Nitrogen requirements of drip-irrigated peppers. HortScience 28:1097-1099.

Iqbal, J. and D. Wright. 1997. Effects of nitrogen supply on competition between wheat and three annual weed species. Weed Res. 37(6):391-400.

Kasirajan, S. and M. Ngouajio. 2012. Polyethylene and biodegradable mulches for agricultural applications: A review. Agron. Sustain. Dev. 32(2):501-529.

Kluchinski, D., and J.W. Singer. 2005. Evaluation of weed control strategies in organic soybean production. Crop Mgt. 4(1).

Knowles, T.C., B.W. Hipp, P.S. Graff, and D.S. Marshall. 1993. Nitrogen nutrition of rainfed winter wheat in tilled and no-till sorghum and wheat residues. Agron. J. 85(4):886-893.

Kristoffersen, P., A.M. Rask, and S.U. Larsen. 2008. Non-chemical weed control on traffic islands: A comparison of the efficacy of five weed control techniques. Weed Res. 48(2):124-130.

Krupinsky, J.M., K.L. Bailey, M.P. McMullen, B.D. Gossen, and T.K. Turkington. 2002. Managing plant disease risk in diversified cropping systems. Agron. J. 94(2):198-209.

Lamont, W.J. 1993. Plastic mulches for the production of vegetable crops. HortTechnology 3:35-39.

Lamont, W.J. 2005. Plastics: Modifying the microclimate for the production of vegetable crops. HortTechnology 15:477-481.

Leblanc, M.L. and D.C. Cloutier. 2001. Susceptibility of dry edible bean (Phaseolus vulgaris, cranberry bean) to the rotary hoe. Weed Technol. 15(2):224-228.
Liebman, M. and A.S. Davis. 2000. Integration of soil, crop and weed management in lowexternal-input farming systems. Weed Res. 40(1):27-47.

Liu, X.J., J.C. Wang, S.H. Lu, F.S. Zhang, X.Z. Zeng, Y.W. Ai, S.B. Peng, and P. Christie. 2003. Effects of non-flooded mulching cultivation on crop yield, nutrient uptake and nutrient balance in rice-wheat cropping systems. Field Crops Res. 83(3):297-311.

Mathiassen, S.K., T. Bak, S. Christensen, and P. Kudsk. 2006. The effect of laser treatment as a weed control method. Biosyst. Eng. 95(4):497505 .

Melander, B. and K. Rasmussen. 2000. Reducing intrarow weed numbers in row crops by means of a biennial cultivation system. Weed Res. 40(2):205-218.

Miles, C., R. Wallace, A. Wszelaki, J. Martin, J. Cowan, T. Walters, and D. Inglis. 2012. Deterioration of potentially biodegradable alternatives to black plastic mulch in three tomato production regions. HortScience 47:1270 1277.

Moreno, M.M. and A. Moreno. 2008. Effect of different biodegradable and polyethylene mulches on soil properties and production in a tomato crop. Scientia Hort. 116(3):256-263.

Munkholm, L.J., R.J. Heck, and B. Deen. 2013. Long-term rotation and tillage effects on soil structure and crop yield. Soil Tillage Res. 127:85-91.

Nyiraneza, J., A. N'Dayegamiye, M.H. Chantigny, and M.R. Laverdière. 2009. Variations in corn yield and nitrogen uptake in relation to soil attributes and nitrogen availability indices. Soil Sci. Soc. Amer. J. 73(1):317-327.

Page, E.R., M. Tollenaar, E.A. Lee, L. Lukens, and C.J. Swanton. 2010. Shade avoidance: An integral component of crop-weed competition. Weed Res. 50(4):281-288.

Pérez-Ruiz, M., R. Brenes, J.M. Urbano, D.C. Slaughter, F. Forcella, and A. Rodríguez-Lizana. 2018. Agricultural residues are efficient abrasive tools for weed control. Agron. Sustain. Dev. 38(2): 18.

Ponce, R.G., C. Zancada, M. Verdugo, and L. Salas. 1996. Plant height as a factor in competition between black nightshade and two horticultural crops (tomato and pepper). J. Hort. Sci. 71(3):453-460.

Roe, N.E., P.J. Stoffella, and H.H. Bryan. 1994. Growth and yields of bell pepper and winter squash grown with organic and living mulches. J. Amer. Soc. Hort. Sci. 119:1193-1199.

Sarkar, S. and S.R. Singh. 2007. Interactive effect of tillage depth and mulch on soil temperature, productivity and water use pattern of rainfed barley (Hordium vulgare L.). Soil Tillage Res. 92(1):79-86.

Sarkar, S., M. Paramanick, and S.B. Goswami. 2007. Soil temperature, water use and yield of yellow sarson (Brassica napus L. var. glauca) in relation to tillage intensity and mulch management under rainfed lowland ecosystem in eastern India. Soil Tillage Res. 93(1):94-101.

Schonbeck, M.W. 1999. Weed suppression and labor costs associated with organic, plastic, and paper mulches in small-scale vegetable production. J. Sustain. Agr. 13(2):13-33.

Taylor, E.C., K.A. Renner, and C.L. Sprague. 2012. Organic weed management in field crops with a propane flamer and rotary hoe. Weed Technol. 26(4):793-799.

Ulloa, S.M., A. Datta, G. Malidza, R. Leskovsek, and S.Z. Knezevic. 2010. Timing and propane dose of broadcast flaming to control weed population influenced yield of sweet maize (Zea mays L. var. rugosa). Field Crops Res. 118(3):282-288.

Wortman, S.E. 2014. Integrating weed and vegetable crop management with multifunctional air-propelled abrasive grits. Weed Technol. 28(1):243-252.

Wortman, S.E. 2015. Air-propelled abrasive grits reduce weed abundance and increase yields in organic vegetable production. Crop Prot. 77: 157-162.

Wortman, S.E., I. Kadoma, and M.D. Crandall. 2015. Assessing the potential for spunbond, nonwoven biodegradable fabric as mulches for tomato and bell pepper crops. Scientia Hort. 193:209-217.

Wortman, S.E., A.S. Davis, B.J. Schutte, and J.L. Lindquist. 2011. Integrating management of soil nitrogen and weeds. Weed Sci. 59(2):162170.

Wortman, S.E., F. Forcella, D. Lambe, S.A. Clay, and D. Humburg. 2018. Profitability of abrasive weeding in organic grain and vegetable crops. Renewable Agr. Food Systems 1-6.

Zhang, Y., E.S. Staab, D.C. Slaughter, D.K. Giles, and D. Downey. 2012. Automated weed control in organic row crops using hyperspectral species identification and thermal micro-dosing. Crop Prot. 41:96-105.

Zhang, H., C. Miles, S. Ghimire, C. Benedict, I. Zasada, and L. DeVetter. 2019. Polyethylene and biodegradable plastic mulches improve growth, yield, and weed management in floricane red raspberry. Scientia Hort. 250:371379.

Zhu, J., N. Tremblay, and Y. Liang. 2012. Comparing SPAD and atLEAF values for chlorophyll assessment in crop species. Can. J. Soil Sci. 92(4):645-648. 